\title{
Ficções de segunda mão: notas sobre o manuscrito
}

\author{
Marcílio França Castro \\ Universidade Federal de Minas Gerais
}

\section{Entre papéis alheios}

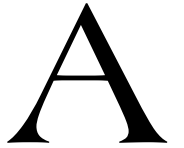

tribuir ficcionalmente a outro a autoria de uma narrativa é procedimento anterior à invenção do livro. Foi, entretanto, depois do surgimento da prensa tipográfica e especialmente a partir do Dom Quixote que o artifício se tornou mais complexo, difundiu-se e passou a afetar de modo irreversível a própria ficção: o narrador, ao mesmo tempo que se empresta o papel de romancista, remete ao manuscrito alheio a fonte da história que conta.

No livro de Cervantes, o suposto autor das aventuras do fidalgo é o historiador Cid Hamete Benengeli, a cujas histórias, escritas em árabe, o narrador-romancista só tem acesso por meio de um tradutor anônimo. Com um repertório até certo ponto variado, a ficção do manuscrito atravessa a era moderna; prolifera no século 18 , sobretudo na Inglaterra, mas também no século 19, e sobrevive, transformando-se, até os dias de hoje, aberta a leituras que nem sempre são óbvias. O procedimento é conhecido: em linhas gerais, o romance se apresenta como a publicação de determinados papéis ou manuscritos (um relato, cartas, memórias, diários, crônicas); fortuitamente ou não, o documento chega às mãos daquele que, na contingência de editor ou redator, organiza o material - como pode ou lhe convém - e o compartilha com o leitor.

Uma extensa lista de romances explora o recurso. A intervenção do redator varia da mera transcrição à reescrita ou à tradução, sempre com a possibilidade de cortes, adaptações, deslocamentos. Vejamos alguns exemplos. Em Júlia ou a nova Heloisa, de Rousseau, publicado pela primeira vez em 1762, o editor organiza e publica a correspondência que envolve dois amantes; no prefácio, 
põe em dúvida os limites da sua participação e também o estatuto da obra: "trabalhei eu mesmo neste livro e não o escondo. Terei feito tudo ou a correspondência é uma ficção?”. ${ }^{1}$ Em As ligaçôes perigosas (1782), de Choderlos de Laclos, o romance constitui-se a partir de uma seleção de cartas, cuja autenticidade é desde logo questionada em uma advertência do editor; o redator que as organiza, por sua vez, declara no prefácio que não teria feito mais do que selecionar o material, com apenas alguns cortes e notas, ainda que desejasse alterações maiores. O editor-romancista de Adolfo (1816), de Benjamin Constant, alguns meses depois de uma viagem a Cerenza, na Itália, recebe do dono do albergue que o hospedara um cofre com algumas cartas e um caderno, que o estalajadeiro não sabia se pertenciam ao primeiro ou a um hóspede excêntrico que estivera lá na mesma época. É o relato contido no caderno que o editor, após esclarecer casualmente a sua origem, resolve dar a público, como "uma história real da miséria do coração humano". $\mathrm{Na}$ advertência, declara: "nada modifiquei do original”. Também é sem nenhuma alteração que os editores de $A$ náusea (1938), de Sartre, afirmam publicar os "cadernos que foram encontrados entre os papéis de Antoine Roquentin". Em A família de Pascual Duarte (1942), de Camilo José Cela, um editor autointitulado transcriptor publica as memórias do protagonista, encontradas em um balcão de farmácia em Almendralejo. Em nota, adverte: "na obra que hoje apresento ao curioso leitor nada me pertence a não ser a transcrição.

São muitos os romances, novelas e contos nos quais, por obra desse intermediário nunca confiável - copista, compilador, escritor - dão-se ao público papéis de segunda mão. A lista inclui ainda obras como Pamela (1740), de Richardson, Delfina (1802), de Mme. De Staël, Os sofrimentos do jovem Werther (1774), de Goethe, o Manuscrito encontrado em Saragoça (1804), do polonês Jan Potocki, ${ }^{2}$ contos de Alan Poe e Merimée. Para não falar de Borges, que, evocando a cultura medieval, explorou à exaustão a idéia da reescrita e da história alheia, além do anonimato e da poligrafia, e fez da

\footnotetext{
${ }^{1}$ ROUSSEAU, 2006, p. 23.

${ }^{2} \mathrm{~A}$ história desse livro carrega curiosidades que ajudam a criar uma espécie de "lenda" em torno dele: Potocki, o autor, apesar de polonês, escreve em francês; a narrativa do manuscrito, por sua vez, é a tradução (escrita) para o francês de um texto que vai sendo lido em espanhol. O livro foi publicado em duas partes: a primeira em 1805, numa edição de São Petersburgo; a segunda, em 1813, foi impressa em Paris.
} 
tensão entre o original e a cópia um dos principais eixos de sua ficção. Óscar Tacca, em Las voces de la novela, investiga muitos desses casos, e acrescenta mais outros tantos à série. ${ }^{3}$

No Brasil, parece ter sido José de Alencar o primeiro a utilizar o tema, pelo menos de forma sistemática. Uma sequiência de prefácios, notas e pósescritos emolduram e fazem dobras nos seus romances; a articulação envolve cartas, explicações, manuscritos e dedicatórias. No prólogo da primeira edição do Guarani (1857), dirigido à prima, o escritor-editor encaminhalhe a versão de um manuscrito que ele e Carlota (a moça que é protagonista de Cinco minutos e cujas cartas, aí transcritas pelo narrador, ajudam-lhe a costurar a história) vinham dedicando-se a decifrar: "quero aproveitar as minhas horas de trabalho em copiar e remoçar um velho manuscrito que encontrei em um armário desta casa, quando a comprei”. Em Lucíola (1862), G.M. comunica, no prefácio dirigido a P. (Paulo), de quem é prima, a reunião em livro das cartas que este lhe enviara. Em Diva (1864), é Paulo quem se dirige a G.M., para enviar-lhe "outro perfil de mulher". Tendo recebido, pelo seguro, uma carta de Amaral, acompanhada de "um volumoso manuscrito", Paulo solicita novamente à prima os favores de editora: "O manuscrito é o que lhe envio agora, um retrato ao natural, a que a senhora dará, como ao outro, a graciosa moldura”. A série continua, formando uma espécie de narrativa perigráfica que articula a obra do escritor. Em Guerra dos mascates (1870), outro documento é posto em cena: trata-se de "um grosso rolo de escrita enleado com um cadarço de Lamego", contendo o "manuscrito de uma crônica inédita da Guerra dos Mascates" - papelada velha a partir da qual se teria alinhavado o romance. Quem dá a explicação é Sênio, narrador-editor que assina o prólogo do livro. Em Senhora (1875), a história não surge propriamente de um manuscrito; entretanto, segundo o narrador afirma no prefácio ao leitor, que leva a assinatura de José de Alencar, o livro não poderia ser atribuído ao escritor, que não passaria "rigorosamente de editor".

É de se notar, pois, que, quando veio à luz, em 1904, a primeira edição de Esaú e Jacó, de Machado de Assis, o manuscrito como tema e recurso narrativo já tinha um certo currículo na literatura brasileira, independentemente do sentido e do peso que se possa conferir à manobra.

${ }^{3}$ TACCA, 1973. 
No romance de Machado, segundo lemos na advertência (não assinada) que abre o romance, a história dos irmãos Esaú e Jacó era a redigida no último dos sete cadernos encontrados na secretária do conselheiro Aires após a sua morte. Os seis primeiros, compostos, diferentemente do último, na forma de diário, são os que vão constituir depois, em 1908, o romance Memorial de Aires. Em nota no pórtico deste livro, com a assinatura de Machado de Assis, o editor-autor comenta a obra e a edição: "Não houve a pachorra de a redigir à maneira daqueloutra, - nem a pachorra, nem habilidade. Vai como estava, mas desbastada e estreita, conservando só o que liga o mesmo assunto.”

É possível citar alguns romances recentes que também recorrem a manuscritos. Silviano Santiago, em 1981, publica Em liberdade, livro cujo estatuto se encontra embaçado desde a capa. Uma elaborada nota, rica em referências biográficas (falsas ou verdadeiras?), esclarece (confundindo) o que é o livro: os diários escritos por Graciliano Ramos durante os meses em que esteve encarcerado na penitenciária de Dois Rios, na ilha Grande, em 1936. O nome que aparece na nota - e se responsabiliza pelo livro - é o mesmo inscrito na capa - Silviano Santiago. A folha de rosto, porém, declara o estatuto da obra: "uma ficção de Silviano Santiago". Também lançando-se nas fronteiras já quase imperceptíveis entre o fato e a ficção, Nove noites (2002), de Bernardo Carvalho - um romance-investigação sobre o suicídio do antropólogo Buell Quain, em 1939, na aldeia dos índios Krahô, na região do Xingu - faz uma intrincada costura de manuscritos (cartas) e relatos alheios. Nesse romance, narrar é montar um quebra-cabeças com peças que não pertencem ao mesmo jogo: "O que agora lhe conto é a combinação do que ele me contou e da minha imaginação ao longo de nove noites", diz a carta-testamento do narrador-personagem transcrita pelo narrador-jornalista.

Uma boa parte da crítica, ao analisar ficções nas quais o artifício dos papéis alheios aparece, costuma vinculá-lo a dois propósitos: a garantia de verossimilhança e o ocultamento do autor, este supostamente atrelado à objetividade da narrativa. Oscar Tacca, referindo-se ao que denomina de ficções de "transcriptor" - o editor dos livros-romances que exemplifiquei resume desta maneira a questão:

El recurso responde, desde sus comienzos, a um doble afán de objetividad y de verosimilitud. Dos caminos diferentes por los que avanza la novela (y que la crítica a menudo intercambia o confunde, cuando a lo sumo se complementan). El primer concepto apunta a la 
imparcialidad del autor. El segundo, a la credibilidad de lo narrado. Por ambas vias la novela pretende caucionar la 'historia'. Por la primera, sustrayendo la figura del rapsoda, del inventor, del embaucador (como diria Borges). Por la segunda, acumulando pruebas e indicios de la realidad del documento. ${ }^{4}$

Essa formulação parece tender a reduzir a ficção do manuscrito a mero índice de verossimilhança, e a tomar a verossimilhança como mecanismo exclusivo da estética realista, vinculado a um suposto esforço histórico do romance para fazer a narrativa parecer mais "objetiva". A necessidade de "eliminação do autor", como parte de uma luta do romance contra a ficção, atenderia também, segundo Tacca, às exigências dessa estética e teria induzido o surgimento do recurso:

A este afán de silencio total o eliminacion del 'autor' há respondido, sin duda, el nacimiento de um antiguo recurso novelesco: el de la transcripción. Recurso detrás del cual se oculta outro afán de mayor alcance e implicación estética: la despersonalización, la objetividad, la verosimilitud. Como ningún outro gênero, la novela pugna contra una de sus dimensiones fundamentales, contra la que más ostensiblemente preside su nacimiento: la ficción. ${ }^{5}$

Essa posição encontrará opositores determinados, como é o caso, por exemplo, de Abel Barros Baptista, que realizou em seu Autobibliografias um longo e complexo estudo sobre o motivo "(auto)bibliográfico' - a "solicitação do livro" - na ficção de Machado de Assis.

A afirmação de Tacca pode ser questionada não apenas por tomar o manuscrito como uma âncora natural da verossimilhança - reduzindo assim a uma precária dimensão a rede de dispositivos com que se conecta e o seu alcance -, mas também porque os conceitos de verossimilhança (necessariamente atrelado ao realismo) e autoria (como discurso inscrito na narrativa ficcional e atribuível a um autor empírico) com que opera são frágeis e comprometem a visão do mecanismo.

\footnotetext{
${ }^{4}$ TACCA, 1973, p. 39.

${ }^{5}$ TACCA, 1973.
} 
Ainda que a verossimilhança seja tópico considerável na relação do manuscrito com o livro em que se converte - e logicamente as instâncias de autoria e narração encontram-se aí também implicadas -, seria necessário antes mudar as bases do edifício no qual se funda a análise de Tacca. A lógica da verossimilhança, pela facilidade com que convence, tende a escamotear ou apagar traços importantes da ficção do manuscrito em livro, que talvez a expliquem melhor, enriqueçam-na e a tornem mais interessante.

\section{II}

\section{O manuscrito como possibilidade (ou exigência) da narrativa}

No primeiro dos três contos que Edgar Alan Poe dedicou a aventuras marítimas, o Manuscrito encontrado em uma garrafa (1833), o narrador conta a história de seu próprio naufrágio, ocorrido durante um passeio no arquipélago de Java, após o navio ter sido surpreendido por um furacão. Uma onda gigantesca varre a barco e atira os passageiros ao mar; miraculosamente, apenas ele próprio e um velho sueco sobrevivem. Os dois passam cinco dias à deriva, e uma nova tempestade os atinge. Presos ao mastro, esses sobreviventes esperam o pior; quando tudo parece perdido, e o navio chacoalha do abismo às alturas no meio das águas, eis que surge na crista de uma onda gigantesca um outro (e impressionante) navio. Sem saber de que jeito, o protagonista é lançado contra a embarcação e alcança-lhe as cordas e a escotilha (o sueco não teria a mesma sorte). Só então, já no meio da história, quando o narrador tenta ocultar-se da tripulação (desnecessariamente, porque ninguém o quer ver), o leitor é informado de como a história é redigida:

[...] ainda não faz muito que me aventurei a penetrar no camarote particular do capitão e de lá tirei o material com que escrevo e tenho escrito. Continuarei, de tempos em tempos, este diário. É verdade que não posso descobrir uma oportunidade de transmiti-lo ao mundo, mas nem por isso deixarei de fazer a tentativa. No derradeiro momento, encerrarei o manuscrito numa garrafa e lançá-la-ei ao mar. ${ }^{6}$

${ }^{6} \mathrm{POE}, 1997$, p. 735. 
A aventura prossegue em clima sobrenatural; tormentas e perigos se sucedem. O navio é demasiado antigo, inexplicavelmente poroso; os tripulantes são todos velhos e enrugados, como "fantasmas de séculos sepultos" - falam um estranho idioma e são incompreensíveis. O final do conto, naturalmente, segue a previsão fatal do narrador, quando o navio corre descontrolado, "rugindo e ululando", rumo ao gelo branco. O leitor está, enfim, diante do manuscrito encontrado em uma garrafa, como diz o título.

É instrutivo pensar no papel que o manuscrito - o diário do náufrago - exerce nesse conto. Trata-se, primeiro, de um recurso de coesão da narrativa: se o narrador desapareceu, como sugere o final, somente por meio do manuscrito encontrado é que o leitor pode ter acesso aos acontecimentos; da mesma maneira, só com o artifício se poderia aceitar a narração da aventura em primeira pessoa, diretamente por quem a experimentou, pressuposto que garante o estímulo e a tensão da história. Ao mesmo tempo que é condição de existência do relato, o manuscrito o costura. Se a aventura está repleta de absurdos, a imagem da redação do texto e de sua descoberta - não menos improváveis - são perfeitamente compatíveis com a lógica fantástica que a governa.

Claro deve estar, entretanto, que o manuscrito, aqui, não tem a função de tornar a história "mais verdadeira", como se ela pudesse "realmente" ter acontecido, ainda que, dissimuladamente, tentem dizer o contrário os esforços do narrador em declarar-se um estudioso da física e da ciência (este parece apenas um jogo para tornar os acontecimentos mais estimulantes). Sua função é, sim, a de amarrar a narrativa dentro da lógica que ela própria solicita e segundo os protocolos de verossimilhança que uma aventura sobrenatural, em seu conjunto, sugere. O conto é, assim, um relato verossímil, apesar de não ser realista. Mas a sua condição ficcional está posta e aceita pelo leitor desde o início.

Isso dito, vê-se perdurar, subjacente à narrativa, a suposição de que os diários de bordo foram encontrados e, por isso, de algum modo, oferecidos ao leitor. Esse dado, tão óbvio que às vezes passa despercebido, provoca um desdobramento na ficção que será crucial na análise de qualquer relato que envolva papéis publicados, mas especialmente o romance. Trata-se de uma ficção de segundo grau, que diz respeito ao modo como se converte um manuscrito em livro. No caso do conto de Poe, em que o jogo da publicação esconde os próprios sinais, se não se pode falar em ficção do livro, pode-se falar pelo menos em ficção da construção da narrativa, de sua descoberta e 
de sua publicação. Talvez seja essa metaficção retraída uma das razões do interesse pelo conto.

Diante da hipótese perturbadora de uma garrafa com um manuscrito boiando no meio do mar, a sua improvável (e por isso excitante) descoberta pode ser, entre tantas descrições fantásticas, a imagem que hipnotiza o leitor. Por um fio improvável e casual, o leitor se conecta ao protagonista, a todo seu pavor e desespero. Sem a garrafa lançada ao mar - e, evidentemente, achada por um editor silencioso - o conto, tal como a personagem, não sobreviveria.

\section{III}

\section{O manuscrito como ficção do livro}

Ao contrário do conto de Poe, que mantém em silêncio o responsável por divulgar o manuscrito, nos romances do tipo epistolar a figura do editorromancista é usualmente convocada e assume a apresentação do romance, como vemos, por exemplo, em As ligaçôes perigosas ou no Werther. Também na publicação de diários, como os de Aires, ou de crônicas restauradas, como o Guarani, o processo de edição do material torna-se explícito e veste a narrativa com os pontos de sua costura. Estamos aqui diante de uma dupla ficção: a ficção da história contada (ou das cartas trocadas), e a ficção da publicação dessas histórias ou cartas em forma de livro - a ficção do livro -, que solicita um autor-editor não menos ficcional.

A presunção da existência do manuscrito é o ponto de partida para a construção do romance e para sua leitura. Não se trata, é claro, de supor que haja prova documental dessa existência, ou do modo como o texto foi encontrado: em um porão, no balcão de uma farmácia ou em um pardieiro. Em alguns casos, a conjectura seria mesmo ridícula. Trata-se apenas de fingir que ele existe, e essa simulação, acatada pelo leitor, funciona como a cláusula primeira de uma contrato ficcional; somente a partir dela é que a narrativa poderá acontecer.

Entretanto, se a presunção do manuscrito é condição para a narrativa, é a própria ficção que vai, de diversas maneiras (às claras ou subliminarmente), insinuar a sua precariedade e denunciá-la como falsa, como faz de forma didática o editor de Júlia ou a nova Heloísa. A originalidade do manuscrito será inquirida, assim como a neutralidade do autor-editor, a confiabilidade do relato e o próprio estatuto do manuscrito, como nota Abel Barros Baptista: 
[...] a presunção do achado permanece intacta e indispensável para a leitura do romance. Num segundo momento, porém, a ficção do manuscrito é a presunção do manuscrito ativada, duplicada: se se quiser, através do caráter inelidível da presunção romanesca, insinuase a precariedade da presunção do manuscrito como lugar original, suporte da identidade e da legibilidade do livro (p. 240)

A ficção do livro dispara uma série de tensōes internas ao romance, que no entanto ecoam fora dele, envolvendo os conceitos de autoria, nome e assinatura; original e cópia; falso e verdadeiro; história e ficção; livro e romance. Esse jogo de duplos e enganos, que relança a narrativa e suas perguntas em um abismo vertiginoso, relaciona-se, historicamente, com a invenção do livro (da prensa tipográfica) e sua associação ao romance. É aí que se incorpora a história da conversão dos originais em livro como motivo romanesco. ${ }^{7}$

A compreensão da ficção do manuscrito como ficção do livro permite voltar à questão da verossimilhança e, quem sabe, reconduzi-la ao seu devido lugar. Para tanto, um pequeno exercício de imaginação será útil. Suponhamos, como ficção epistolar, um romance que adotasse como opção narrativa a exibição de cartas diretamente ao leitor, sem a interferência mediadora que dirige a recepção dos textos, como é comum. Esta seria uma construção romanesca cujas regras o leitor teria de descobrir no percurso da leitura. A articulação interna da narrativa (sua verossimilhança) se faria apenas pelos laços entre as cartas, pelas pistas que o leitor fosse juntando no correr das correspondências, como, aliás, acontece na leitura de qualquer romance (ou de um jogo) desconhecido. A verossimilhança de estarem essas cartas reunidas e dadas à leitura se construiria talvez sem uma explicação prévia e se submeteria a outro diagrama; não dependeria de nenhum prólogo ou advertência (talvez apenas do título), ainda que, no final, chegasse de algum modo à idéia de que um livro foi constituído, analogamente ao que ocorre no conto de Poe com a publicação do manuscrito encontrado na garrafa.

Bem, pode-se concluir daí que não é a declaração inscrita no prefácio ou a figura do editor que, por si sós, vão dar verossimilhança ao romance, do mesmo modo que não é a presunção do manuscrito que o faz. Nenhum desses elementos é, por si só e diretamente, índice de verossimilhança (ou

\footnotetext{
${ }^{7}$ A esse respeito, ver BAPTISTA, 2003, p. 241.
} 
de ilusão de realidade, se admitirmos que o código aqui é realista), porque a verossimilhança (e também a ilusão realista que, em certos casos, pode adjudicar-se a ela) só existe no êxito com que esses elementos são articulados. É o romance como ficção do livro que solicita esses elementos. O que está em jogo, pois, é a ficção da transformação do manuscrito em livro e a capacidade romanesca de brincar com as possibilidades de sua realização, como sugere Abel Barros Baptista:

Quando a teoria e a história do romance se detêm neste motivo, a relação entre o livro tipográfico e o manuscrito permanece geralmente implícita, para não dizer de todo ignorada, o que é apenas um aspecto da negligência decisiva, a saber, a que ignora que o motivo do manuscrito encontrado (ou recebido, ou entregue para publicação etc.) é sobretudo uma ficção da transformação do manuscrito em livro, portanto, uma componente da ficção romanesca do livro, motivo autobibliográfico, em suma. ${ }^{8}$

Assim, o romance do "transcriptor", para usar o termo de Óscar Tacca, não almeja a verossimilhança mais do que nenhum outro romance; também não pretende ser mais documental ou realista que qualquer outro. Não duela contra a ficção; ao contrário, intensifica-a, na medida em que simula não apenas o jogo, mas também as regras do jogo, e acaba, ironicamente, por desconstruí-lo. É esse o paradoxo fundamental que percorre toda a ficção de segundo grau: sua tendência a corroer e pôr em dúvida o próprio código que a sustenta, podendo libertar-se dos seus pressupostos e até mesmo, no caso do romance epistolar, daquelas cartas que o tornaram possível. Cito novamente Barros Baptista:

[...] a ficção do manuscrito produz justamente o efeito oposto à verossimilhança: revela, antes do mais, que a possibilidade de o livro se autonomizar e cortar o acesso à correspondência original não representa um risco contingente que uma prévia definição do livro possa autoritariamente prevenir, mas uma condição inerente à própria passagem dos manuscritos para o livro, pelo que o romance epistolar estará sempre marcado pela indecisão entre o livro que transcreve uma

${ }^{8}$ BAPTISTA, 2003, p. 241. 
correspondência e o livro que forja uma correspondência, entre o livro que recolhe as diferentes dicções dos diferentes correspondentes e o livro em que um mesmo autor se esforça, com sucesso ou sem ele, por dissimular a sua presença numa diversidade artificial: uma indecisão, pois, entre a carta autêntica e o exemplo ficcional de carta autêntica. ${ }^{9}$

\section{IV}

\section{O manuscrito como jogo metaficcional}

A invenção da imprensa não abalou o prestígio do manuscrito. Pelo contrário, a possibilidade de reprodução tipográfica de textos reforçou a preocupação com o estabelecimento de fontes únicas e confiáveis para a composição do livro - os originais ${ }^{10}$. O manuscrito, em torno do qual se construiu durante séculos uma tradição de identidade, definida pela relação necessária entre o texto e o corpo (escrever e copiar), passa a funcionar no novo sistema como a autoridade capaz de submeter o livro e garantir a sua autenticidade.

A força simbólica dessa tradição é de certa forma transportada para a ficção, que incorpora como tema o manuscrito. Mas é também na ficção que essa reverência vai ser denunciada, da mesma maneira que as presunções que a tornam possível. Se um livro, para ser aceito, pressupóe a fidelidade ao original, é a ficção do livro que a abalará; se o sentido da ficção provém da intenção do autor, é por meio da ficção do livro que essa responsabilidade será interrogada.

Hans Ulrich Gumbrecht assinala o momento de passagem do manuscrito ao livro como aquele em que o sentido do texto deixa de ser associado à situação em que se realiza -na qual, de um modo ou outro, é acionado por um de seus executores anônimos (um trovador, numa leitura pública, ou um copista, num exercício de escrita, designados por uma mesma palavra, auctor) - para ser requisitado pela figura que assina a capa do livro publicado - o autor moderno, aquele que detém a intenção. ${ }^{11}$

\footnotetext{
${ }^{9}$ BAPTISTA, 2003, p. 252.

${ }^{10}$ REYNOLDS, 1995, p. 153. BAPTISTA, 2003, p. 232-234.

${ }^{11}$ Sobre a relação entre corpo e texto na cultura medieval, consulte-se GUMBRECHT, 1998, p. 73-76; e McLUHAN, 1972, p. 132.
} 
A idéia do autor como fonte do sentido, porém, no momento mesmo em que tenta se estabelecer, parece desde logo ironizada pelo romance que faz a ficção do manuscrito. Não seria outra a sugestão oferecida pela figura do padrasto da história do Dom Quixote, o narrador-romancista (um duplo de Cervantes) que assina o livro mas não pode responder por sua narrativa - uma confusa redação da qual participaram Cid Hamete, o tradutor árabe e ele próprio - e assim nem por seus efeitos ou por sua interpretação.

É possível, também, que já desponte aí, no espaço em branco que essa "irresponsabilidade" do autor sugere, a imagem da obra inacabada, tanto no sentido escritural, de que um texto é sempre emendável, como no de que não se pode confinar à vontade de nenhum daqueles que participaram de sua escrita o modo de interpretá-lo ou fruí-lo. Gênero desde sempre desamarrado e vacilante, ainda desacostumado à narrativa linear e longa ${ }^{12}$ - o romance inventa aqui uma espécie de resistência a uma das limitações que o livro tipográfico, por conta de sua materialidade, tenta impor-lhe, a unidade e o acabamento, e, curiosamente, começa a ficcionalizar um circuito de realização da escrita que é típica do mundo que vai ficando para trás - o medieval. O manuscrito sai da história para entrar na ficção, e arrasta consigo uma côrte de amigos e ajudantes. Isso só é possível, porém, com a invenção do livro ${ }^{13}$.

Assim, o mesmo manuscrito que remete à originalidade e à verdade, é também o que vai sugerir a falsidade do livro. $\mathrm{O}$ romance, irmão do livro, ao mesmo tempo que se desenvolve junto com ele e sob as suas regras (de unidade, de contenção, de educação), também é o que resiste a ele e o modifica. ${ }^{14}$

A tensão entre romance e livro, com todos os seus jogos, fará do território da autoria um campo de perturbação e disputa contínuas. Considerando em especial a ficção do manuscrito, Óscar Tacca afirma que, "desde el siglo 18 adelante, la marcha de la novela tiende progresivamente

\footnotetext{
${ }^{12}$ V. McLUHAN, 1972, p. 187 e 190-191.

${ }^{13}$ Mais interessante ainda é pensar, hipoteticamente, que esse movimento de incorporação à ficção de certos traços constitutivos da cultura escrita medieval - escritores anônimos, copistas, textos apócrifos, histórias de segunda mão - poderia ser rastreada na literatura ocidental como uma espécie de movimento em mão oposta à configuração do estatuto moderno (iluminista) da autoria, da criação e da escrita, até emergir em nomes como o de Jorge Luis Borges.
}

${ }^{14}$ V. BAPTISTA, 2003, p. 60 e 233. 
al secuestro del autor. Del texto de la novela, ela autor pasa al prefacio. Y este, poco a poco, se reduce hasta desaparecer" ${ }^{15}$. Interroguemos essa afirmação. É verdade que, com a devida cautela, podemos aproximar a narrativa biográfica de um autor de certos aspectos de sua narrativa ficcional, e muitas leituras críticas o fazem; também é certo que muitas vezes, por exceções históricas ou razões institucionais (ou até mesmo estéticas), o autor de um livro possa esconder-se sob pseudônimo ou produzir romances com propósito declaradamente engajado. Ainda que contestáveis, por meio desses laços podemos de algum modo confrontar o escritor de um romance e a ficção que a ele se atribui. Entretanto, não parece seguro imaginar, como faz Tacca, que o autor de algum modo esteja cumprindo, ao longo dos últimos séculos, uma trajetória de fuga do romance, simplesmente pelo fato de que ele nunca pertenceu ao romance ou se inscreveu nele como tal, ainda que o seu nome posto no prefácio ou na própria trama nos dê razões para duvidar disso.

Em perspectiva histórica, talvez seja menos arriscado dizer que o que houve, e tem havido, foi sim uma mudança nas formas de simular a autoria e de ficcionalizá-la, uma transformação no regime ficcional da autoria, que inclui tanto os mecanismos de construção quanto os de recepção da ficção autoral. De qualquer modo, não seria lícito falar aqui em seqüestro do autor, porque jamais seria atribuível ao autor-escritor, pelo menos a princípio, a responsabilidade direta pelo ato de fala de qualquer personagem ou mesmo de um editor-romancista, no caso da ficção do manuscrito.

Ainda que o autor introduza em um prefácio ou nota o seu próprio nome, ou que, deliberadamente, crie artifícios para tentar conduzir a leitura do romance, como ocorreu já nos primórdios da tipografia, essas intervenções, ao compor o romance, ingressam, ainda que ambiguamente, no circuito da ficção do livro e passam a fazer parte dela. Afinal, quem assina o prólogo de Dom Quixote?

A respeito dessa fronteira arriscada entre personagem e autor, Sergio Waisman, tradutor da obra de Ricardo Piglia para o inglês, conta uma história interessante:

Cuando em 1993 empecé a traducir parte de la obra de Piglia al inglés, no comprendía enteramente em qué me estaba metiendo. A cierta

${ }^{15}$ TACCA, 1973, p. 35-36. 
altura envié um fax a Buenos Aires para preguntarle a Piglia como debía manejar las numerosas citas de Nombre Falso. [...] Piglia me decía que no confrontase nada, que tradujese solamente su texto. Y añadía: "Las citas debés traducirlas directamente... Pienso las citas como si fueran personajes (el señor Freud, el señor Melville, el señor Lenin), por lo tanto no importa si son apócrifas o verdaderas... Cuando el personaje es conocido... su nombre funciona de manera distinta a cuando es desconocido y produce cierto efecto enigmático (quien será? Será real o inventado?).”16

O jogo do manuscrito, ao invés de afastar o autor, como quer Tacca, pode aproximá-lo terrivelmente - e confundi-lo, torná-lo outro -, porque inscreve ficcionalmente a autoria, usando, em alguns casos, o próprio nome do escritor. Quando Alencar põe seu nome no prólogo de um romance está, de certa maneira (ainda que não tenha pensado nisso), também tornandose parte dela. Quando Sênio assume o papel, altera-se o diagrama da ficção. Quando Paulo ou G.M. organizam um volume, ou quando o editor do romance é apócrifo, não está desaparecendo o autor, é o processo autoral está sendo simulado de maneira diferente. E, quando Silviano Santiago aparece no prefácio de Em liberdade, chamando a si "toda a responsabilidade da publicação”, o que está fazendo o escritor senão emprestando o seu nome à ficção e criando uma turbulência para fazer o livro mais curioso e atraente?

\section{V \\ O manuscrito como forma de atração do leitor}

O impacto simbólico que a imagem do manuscrito é capaz de provocar no leitor do romance não pode de modo algum ser negligenciado, sobretudo quando o procedimento se expande de maneira excepcional, como ocorreu no século 18 inglês.

Aqui, é também a necessidade de dar "verossimilhança" aos relatos que costuma ser invocada para explicar a disseminação do artifício nesse período, e na construção do argumento a verossimilhança acaba outra vez confundida com ilusão referencial e senso de realidade. Sandra Guardini de Vasconcelos,

${ }^{16}$ WAISMAN, 2005, p. 236-237. 
por exemplo, em respeitável estudo sobre a formação do romance inglês, faz o seguinte comentário:

O recurso ao truque do velho manuscrito ou das cartas que foram confiadas ao escritor, que se apresenta como mero editor, atravessa todo o século, aparecendo desde cedo nas obras de Defoe, reaparecendo em Richardson, em Horace Walpole e ainda, em 1785, na advertência ao leitor de The Recess, de Sophia Lee. [...]

São, sem dúvida, recursos de quem quer dar "um ar de verdade" à narrativa, para atender a exigência de plausibilidade e verossimilhança, palavras de ordem no período, desde o prefácio de Mary Delariviere Manley a The Secret History of Queen Arah, de 1705. É certamente em busca de credibilidade que Manley e, mais tarde, o anônimo autor de The Highland Rogue (1724) se perguntam como fazer para reproduzir palavra por palavra a fala de um personagem, numa cena em que não poderiam estar presentes, sem romper com a verossimilhança de seus relatos. ${ }^{17}$

O fato de, na época, as técnicas de verossimilhança e efeito de realidade estarem no centro do debate literário - como parte do exercício intelectual de escritores que, experimentando o novo gênero, queriam aperfeiçoar a sua arte, além de fazê-lo "edificante" e prazeroso - parece não autorizar a caracterização direta do uso do recurso do manuscrito como mais um, entre outros, dos truques de efeito realista.

A meu ver, é duvidoso que a edição de cartas possa ser realmente afirmada como uma tática de "de quem quer dar um 'ar de verdade' à narrativa, para atender à exigência de plausibilidade e verossimilhança”. Primeiro (e mais uma vez), porque não se pode reduzir a verossimilhança à estética realista (ainda que sejamos muitas vezes tentados a isso); segundo, porque, ainda que estejamos falando de um romance construído dentro da lógica realista, a figura do manuscrito não se impõe à ficção, por si só, como elemento simulador de verdade; é o romance, como ficção do livro, que a solicita e incorpora como um de seus elementos. E, mais, seja qual for a relação entre manuscrito e verossimilhança ou efeito de verdade, a função do manuscrito não pode ser avaliada no mesmo plano da "fala das personagens". A primeira diz respeito à ficção do livro; a segunda, à história narrada.

${ }^{17}$ VASCONCELOS, 2008, p. 7. 
Não poderia entrar nos detalhes dessa discussão. Gostaria apenas de acrescentar mais uma hipótese às que aqui esbocei para explicar o manuscrito (exigência da narrativa, ficção do livro e jogo metaficcional), nenhuma delas excludente em relação à outra. Parto da suposição, exposta anteriormente, de que a tradição e a autoridade do manuscrito, ainda que imediatamente denunciadas, foram transportadas simbolicamente para a ficção, a partir do momento em que o romance começou a contar a história de como se transforma um manuscrito em livro.

Bem, sabemos que o romance no século 18 inglês é um gênero novato, resistente aos padrões clássicos e assim, do ponto de vista moral, perigoso, pela liberdade com que pode violar o decoro e as regras de comportamento social. A própria Sandra Guardini observa:

Recém-chegado à cena literária, ao romance faltavam tradição e sangue nobre. Em que pesem as tentativas de dar-lhe uma ascendência, associando-o à épica, ele era, na verdade, um 'parvenu de la république de lettres'. Numa época em que se valorizava a polite literature, a arte a cultura altas eram restritas ao consumo de um elite que as considerava sinal de refinamento e distinção. ${ }^{18}$

Posto à prova, o novo gênero faz um esforço muitas vezes programático para conquistar a confiança do leitor sem ser destruído pela censura. Arriscase em manobras variadas, experimenta temas, recursos, e também os discute ensaisticamente. Uma incontinência formal o caracteriza, uma desorientação de "termos, de critérios, de exigências, de propósitos"19 que o faz alimentarse de outros gêneros, influenciá-los, como uma máquina de possibilidades. Quando deseja aproximar-se do leitor e de seu cotidiano, e tocá-lo em sua intimidade, o romance tem de assegurar a esse leitor (e aos críticos e suas convenções) que o percurso é seguro e que a aventura não o corromperá. Nesse caso, seria recomendável equipar o romance, de forma consciente ou não, com algum aparato da tradição e da segurança, muni-lo com o lastro que de algum modo respondesse aos apelos da autoridade clássica, por um lado, e da moral edificante, por outro. Mas sem, afinal, perder a sua liberdade.

\footnotetext{
${ }^{18}$ VASCONCELOS, 2008, p. 6.

${ }^{19}$ VASCONCELOS, 2008, p. 5.
} 
A força simbólica de que se reveste o signo do manuscrito - carta, documento, diário - talvez tenha sido capaz, nesse contexto, de contribuir para a simulação da autoridade de que o romance necessitava. Essa é a hipótese que apresento. Pôde, quem sabe, o manuscrito, herdeiro de uma longa e consagrada tradição, emprestar ao imaginário do leitor o conforto de uma paternidade, à qual, consentindo com o fingimento, o leitor aderiu de bom grado. Seria o manuscrito uma função capaz de invocar a formalidade e a originalidade e a nobreza que servem de âncora para o gênero e de sedução para o leitor - um pai, enfim. Todos podem fingir juntos a mesma cena: "era uma vez um manuscrito".

É evidente que não se trata aqui de enganar o leitor, hipótese que subestimaria a sua inteligência e que é refutada pelos próprios romances, que nos dão pistas suficientes da instalação de um pacto de ficcionalidade para a sua leitura. As cartas e os papéis achados, como manuscritos que são, apenas estimulam o imaginário, talvez subliminarmente, a convocar uma ascendência necessária: um pai, uma família. Seria este um artifício de atração com o qual o leitor, aderindo à farsa, poderia sentir-se confortável com o livro.

É preciso levar em conta, também, que, do ponto de vista tipográfico, o manuscrito é, pelo menos presumidamente (já que o próprio romance vai se encarregar de sugerir o contrário), o modelo ao qual todas as cópias devem fidelidade. A correspondência do livro com o manuscrito original é condição para a leitura, condição posta sob suspeita pelas ficções de transformação do livro em manuscrito, como podemos ver na abertura de Júlia ou a nova Heloisa, de Rousseau.

Explorando um pouco mais a noção de originalidade, seria curioso lembrar o processo de deslocamento semântico pelo qual passa o termo exatamente no século 18 inglês, de acordo com Ian Watt:

É significativo o fato de a corrente partidária da originalidade ter encontrado sua primeira grande expressão na Inglaterra e no século 18; a própria palavra "original" - que na Idade Média significava "o que existiu desde o início" - passou a designar o "não derivado, independente, de primeira mão"; e quando, em suas Conjectures on original composition (Conjeturas sobre a composição original) (1759) - obra que marcou época -, Edward Young saudou Richardson como "um gênio moral e original", o termo podia ter o elogioso sentido de "novo em caráter ou estilo". ${ }^{20}$

${ }^{20}$ WATT, 1996, p. 16. 
Ora, é exatamente $o$ manuscrito o signo no qual se cingem à perfeição os dois sentidos em causa: é original o manuscrito porque é modelo e fonte para os outros textos, porque é a origem do livro; é também original o manuscrito porque traz o que de mais novo a ficção consegue produzir, possível apenas com o advento do romance-livro: a ficção do próprio manuscrito. Essa dualidade funciona como metáfora preciosa daquilo que o romance, a essas alturas, representa: livro e ficção do livro; criação e dissolução demoníaca dos novos e velhos papéis.

Mas a propriedade do manuscrito para levar adiante esse comércio imaginário não pára por aí. É notável, também, a sua capacidade de sugerir ao leitor a intimidade do escritor, como se o prolongasse ou fosse uma emanação direta dele. Mesmo hoje (talvez mais), a escrita à mão fascina. $\mathrm{O}$ papel e a tinta (o corpo do manuscrito) conduzem à carne de quem escreveu, à sua respiração e ao seu microcosmo, como a realização de contato impossível (e às vezes obsceno). Evocar o manuscrito é explorar o universo íntimo do outro, o lugar proibido; o romance-livro vai se aproveitar dessa faculdade. A ficção da edição do manuscrito em livro - uma porta entre o privado e o público - funcionaria como um instrumento perfeito para transformar a confidência em lição.

A ficção do manuscrito (em livro) parece ser, assim, uma opção conveniente como forma de conciliar tradição (necessária) e intimidade (almejada). Talvez seja preciso autenticar o êxito dessa farsa imaginária (para inglês ver) como motivo da proliferação do tema do manuscrito no século 18 - e como mais uma forma de ler tais papéis.

\section{VI}

\section{Última nota}

A idéia do livro como ficção do manuscrito pode ser um bom ponto de partida para a revisão da leitura de certos escritores brasileiros. Nessa linha, para não falar de Machado de Assis, desperta curiosidade a obra de José de Alencar, que, na perigrafia de seus romances, usou de maneira sistemática a idéia do manuscrito (prólogos, prefácios, notas, advertências e pós-escritos), com formulações variadas.

Vista em conjunto, a obra de Alencar enche-se de franjas e dobraduras, criando uma zona de transição discursiva e textual cujo estatuto duvidoso requisita um olhar capaz de saltar da realidade à ficção, da narrativa à 
metanarrativa, do romance ao livro. Essa região do romance, além de estabelecer os protocolos de entrada e saída da narrativa (a comunicação com o leitor) e ativar o diálogo com a crítica, parece também aceitar um roteiro próprio, quem sabe já próximo daquele ponto de decolagem que a tornaria uma ficção autônoma do livro. Graciliano Ramos, Cyro dos Anjos, Silviano Santiago e Bernardo Carvalho, entre outros, também poderiam ser rastreados sob a mesma perspectiva.

A ficção do manuscrito põe em cena a própria escrita e uma tradição, nascida com o livro: a preparação dos textos para publicação. Curiosamente, no romance contemporâneo, essa tradição parece atualizar-se de modo surpreendente, chegando mesmo a sugerir, em alguns casos, que a sobrevivência da narrativa (e do romance) em um mundo saturado de signos pode depender (como gostaria Borges) da capacidade de recolher e rearranjar histórias alheias. Não é outra a lição que o narrador de Mongólia (2003), de Bernardo Carvalho, oferece ao leitor quando, dizendo-se escritor fracassado e mero transcriptor dos diários que compõem o texto, afirma: "A literatura quem faz são os outros". ${ }^{21}$

À volta com textos que não são seus, a figura desse narrador-scriptor, à margem da autoria, mas confundindo-se com ela (e fazendo-a outra), pode dar-nos um belo roteiro de visita ao romance, desde o Dom Quixote. Seria possível encontrar aí - como herdeiros dos escribas e dos profetas - copistas, editores, redatores, escreventes, revisores, tradutores e a legião de duplos que sempre acompanha os acompanha. O que eles podem dizer dos romances que ajudaram a construir?

${ }^{21}$ CARVALHO, 2002, p. 182. 


\section{Referências Bibliográficas}

ALENCAR, José de. O guarani. São Paulo: Ática, 1984.

ALENCAR, José de. Sonhos d' ouro. São Paulo: Ática, 2003.

ALENCAR, José de. Obra completa. Rio de Janeiro: José Aguillar, 1958-1960, 4 v.

ASSIS, Machado de. Esaú e Jacó. Rio de Janeiro; Belo Horizonte: Garnier, 1988.

ASSIS, Machado de. Memorial de Aires. Rio de Janeiro; Belo Horizonte: Garnier, 1988.

BAPTISTA, Abel Barros. Autobibliografias. Campinas: Editora da Unicamp, 2003.

BOECHAT, Maria Cecília. Paraísos artificiais: o romantismo de José de Alencar e sua recepção crítica. Belo Horizonte: Ed. UFMG, 2003.

CARVALHO, Bernardo. Nove noites. São Paulo: Companhia das Letras, 2002.

CARVALHO, Bernardo. Mongólia. São Paulo: Companhia das Letras, 2003.

CELA, Camilo José. La familia de Pascual Duarte. Madrid: Destino, 2003.

CERVANTES, Miguel de. Dom Quijote de la Mancha. Madrid: Real Academia Española, 2004.

CONSTANT, Benjamin. Adolfo. Ediouro, s/d.

GUMBRECHT, Hans Ulrich. Modernização dos sentidos. São Paulo: Ed. 34, 1998.

LACLOS, Choderlos. As ligaçôes perigosas. São Paulo: Círculo do Livro, s/d.

McLUHAN, Marshall. A galáxia de Gutenberg. São Paulo: Editora Nacional/ Edusp, 1972.

WATT, Ian. A ascensão do romance inglês. Trad. Hildegard Feist. São Paulo: Companhia das Letras, 1990.

POE, Edgar Allan. Manuscrito encontrado numa garrafa. In: Fiç̧ão completa, poesia e ensaios. Rio de Janeiro: Nova Aguillar, 1997. p. 729-738.

POTOCKI, Jan. Manuscrito encontrado en Zaragoza. Madrid: Alianza Editorial, 2003.

REYNOLDS, Leighton D.; WILSON, Nigel G. Copistas y filólogos. Madrid: Gredos, 1986.

ROUSSEAU, Jean-Jacques. Júlia ou a nova Heloísa. São Paulo: Hucitec, 2006. 
SANTIAGO, Silviano. Em liberdade. Rio de Janeiro: Rocco, 1994.

SARTRE, Jean-Paul. A náusea. Rio de Janeiro: Nova Fronteira, 2006.

TACCA, Óscar. Las voces de la novela. Madrid: Gredos, 1973.

VASCONCELOS, Sandra Guardini Teixeira. A formação do romance inglês: ensaios teóricos. São Paulo: Aderaldo \& Rothschild; Fapesp, 2007.

VASCONCELOS, Sandra Guardini Teixeira. Formação do romance brasileiro: 1808-1860. Disponível em: <http://www.unicamp.br/iel/memoria/Ensaios/ Sandra/sandra.htm>. Acesso em: jan. 2008.

WAISMAN, Sergio. Borges y la traducción. Buenos Aires: Adriana Hidalgo Editora, 2005.

\section{Resumo}

Pelo menos desde o Quixote, a apresentação de um romance ou relato como edição de manuscritos alheios tem sido procedimento narrativo recorrente. $\mathrm{O}$ propósito do artigo é discutir o sentido e as funções desse artifício.

\section{Abstract}

At least since Don Quijote, it has become a recurrent narrative procedure to structure a novel or story by means of the transcription of somenone else's manuscripts. The purpose of this paper is to argue the meaning and uses of such resource. 